らつ血性心不全患者における血中カテュールアミンの肝での代謝

\author{
横浜市立大学医学部第二内科（主任 金子好宏教授） \\ 小林 公也
}

\title{
STUDIES ON THE HEPATIC INAGTIVATION OF CIRCULATING CATECHOLAMINES IN PATIENTS WITH CONGESTIVE HEART FAILURE
}

Kiminari KOBAYASHI, MD

The Second Department of Internal Medicine, Yokohama Gity University School of Medicine

\begin{abstract}
概要 肝はcatechol-O-methyltransferase, monoamine oxidase多量に含み, 循環血中のcatecholamine (CA) の不活化に一定の役割を演していると考えられる. 今回ヒトの肝での血中CAの代謝率を 調べる目的で, 肝静脈血と動脈血を同時採血し, おのおのの血中CA值を測定した. 対象は高血压症を 含む種々の心疾患患者38例で, 血中CA值はRenzini一三浦変法によりTHI法で測定した. 肝のCA代謝率 は, (動脈血 $\mathrm{CA}$ 值一肝静脈血 $\mathrm{CA}$ 值) $\div$ 動脈血 $\mathrm{CA}$ 値 $\times 100(\%)$ で求め, さらに心内压, 熱希釈法で 心拍出量, ICG法で肝血流量を同時に测定した. 症例を肝正常群28例, うつ血性肝腫大群 8 例, 褐色 細胞腫 2 例に分け検討した. 肝のCA代謝率は肝正常群ではnorepinephrine (NE) $71.3 \pm 2.3$ (SE) \%,

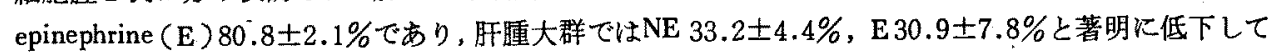

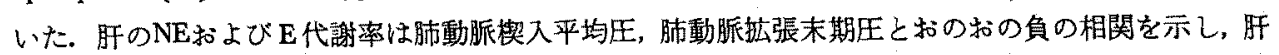
のCA代謝率は心不全の悪化にほ注比例して低下すると考えられた。褐色細胞睡患者では高い血中CA 値を示す一方, 肝のCA代謝率は正常で多量のCAが不活化されて扎り, 正常の肝でのCA代謝の容量は 非常に大きいと考えられた．循環血中のCA濃度は体内でのCAの分泌量と消失量との総和であり，5 つ血性心不全患者に猢る血中CA值にも，肝のCA代謝率の低下が一部関与している可能性が考えら れる.
\end{abstract}

\section{緒 雪}

循環血中のcatecholamine (CA) の消失機序と しては, 種々の組織への取り込みが重要と考えら れ，これには交感神経末端への取り込み（uptake 1), 神経以外の組織への取り込み (uptake $2^{1)}$ ), および肝や肺等の臟器への取り込みがあげられ る.取り込まれたCAは細胞内で代謝を受け不活 化されていくが，この代謝の過程にはcatechol-Omethyltransferase (COMT), monoamine oxidase

〔昭和55年 3 月 24 日受稿〕
(MAO)の両醭素が関与し，特に循環血中のCAの 代謝にはCOMTが重要と考兵られている。これら の酵素は全身の器官, 組織に広く分布するが肝 ${ }^{2\rangle}$ には特に多量含まれており, 又一方では肝静脈 血のCA濃度 ${ }^{3)}$ が 体内各所の血中CA濃度の中で最 も低いことから，肝が血中CAの消失にある役割 を演していると考えられる。この肝のCA代謝に 括ける役割について，Elliott")らはネコでepinephrineによる昇圧反応を投与部位を変えて比較 し, 門脈内注入時の昇圧反応が頙静脈に注入した 時のそれより弱いことを述べ，肝でのCAの消失 
を示唆したが，実際はヒトに扣いて肝で循環血中 のCAはどの程度の代謝を受けて和り，又病的状 態でどの様に変化するかについては不明の点も多 い. 現在心疾患の診断あるいは心血行動態の測定 に際し，心カテーテル検査を含む種々の観血的検 查法が用いられるが，そのカテーテル操作に怙い て先端を肝静脈に插入し曲がりをつけることが多 く行なわれ，又この時容易に肝静脈血を採血する ことができる.今回著者はこれらの諸検査に際し 得られた肝静脈血, 動脈血の血中CA濃度を測定 して肝でのCAの代謝率を求め，又らつ血性心不 全による肝腫大を伴ら患者に拉いて，この代謝率 がどの様に変化するかを比較し，血行動態との関 連と合わせて検討した。

\section{対象ならびに方法}

\section{1. 対象}

当教室に入院中の高血王症を含む種々の心疾患 患者38例で，男性20例，女性18例，年命は18才か ら62才である. 疾患は心弁膜症 9 例，虚血性心疾 患 7 例，先天性心疾患 4 例，心筋症 3 例，不整脈 1 例, 本態性高血圧症 7 例, 褐色細胞腫 2 例, お。 よび胸痛の訴えがあり，諸検査にて正常と思われ る者 5 例である。これらの診断は臨床症状，胸部 レントゲン線写真, 心電図, 心エュー図等によつ て行ない，又本険查に平行して施行された心カ テーテル 検査，各種血管造影検査等により確定 した。，心不全の症状は全く認められない例から NYHA機能分類のIV度まで種々の程度の例が含ま れ，この内心弁膜症および先天性心垁患の 8 例は 進行したらつ血性心不全の結果, 肝腫大が認めら れた。

薬剂は心不全が強く，利尿薬や強心配糖体が中 止できない例はそのまま投与を続けたが，交感神 経遮断薬や血中CA測定值に直接影響を与える薬 物は中止してある.

\section{2. 方法}

検查は肝静脈血採血と肝血流量測定については 別に患者の同意を得た後, 朝食以後を絶领食とし 午後施行した．前処置は特に行なわなかつた。
Seldinger法にて大腿静脈より肝静脈へCournand カ テーテルを進め, 安静恒常状態にあことを確か めた後, 肝静脈血と，直接穿刺法にて大腿動脈よ り動脈血とを同時に採血した。15例では肘静脈よ り末梢静脈血を同時に採血し比較した。

20例ではこのカテーテルを使用して引き続き右 心カテーテル検査を行ない, Stetham P 23圧トラ ンスデューサーにて肺動脈楔入王, 肺動脈圧, 右 室圧，右房圧を測定，次いでSwan-Ganzカテーテ ルを肺動脈に插入し，心拍出量を熱希䣋法によ り Edward cardiac output computerを用い測定し た. 13例では前記の肝静脈に挿入したカテーテル を使用し，旰血流量をインドサイアニングリーン を用い色素希釈法 ${ }^{5}$ にて測定した。 症例によりさ らに必要な左心カテーテル検查, 各種の造影検 查，心腔内心電図記録等の諸検查はこの後おのお の施行した。

採血した血液は氷中のスピッッに移した後速や かに冷凍遠沈し，その血清を分離して測定まで一 $20^{\circ} \mathrm{C}$ 以下に保存した。血中CA值はRenzini-三浦変 法6)によるTHI法で測定し, 肝でのCA代謝率を次 式により求めた。

肝のCA代謝率 $=$ (動脈血 $\mathrm{CA}$ 值一肝静脈血 $\mathrm{CA}$ 值) $\div$ 動脈血CA值 $\times 100(\%)$

各測定値は平均值士標準誤差值で示し, 推計学 的検定法はt検定によつた。

\section{結 果}

褐色細胞腫 2 例を除く36例を次の 2 群に分け検 討した. I . 肝正常群28例，心不全の無い例およ

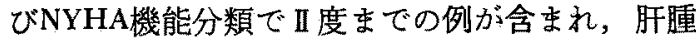
大涊認められず，又血液生化学的に肝機能に 異 常をみない，I．肝腫大群 8 例，NYHA機能分類 でII，IV度の例が含まれ，右季助部に 2 から 5 横 指の弾性硬で時に圧痛のある肝腫大を認める．血 液生化学検查ではこの内 5 例に種々の肝機能障 害がみられた。褐色細胞腫 2 例は別個に検討し た.

1. 血中norepinephrine (NE) 值（表 1，図 1) 

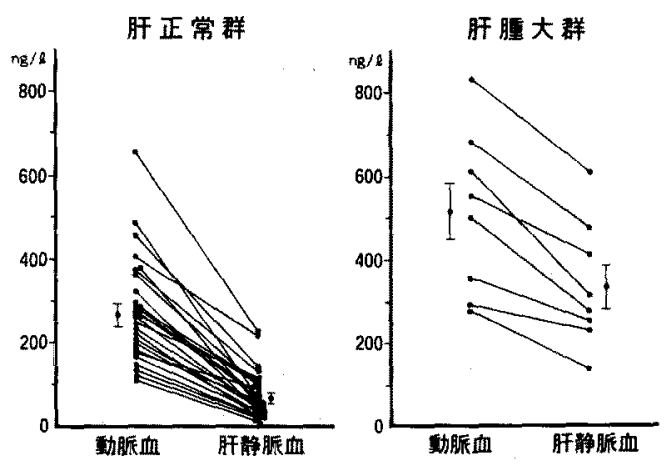

因 1，血中NE值

表 1. 血中CA値 $(\mathrm{ng} / \mathrm{l})$

\begin{tabular}{|c|c|c|c|c|}
\hline & & 的明血 & 肝部㟲血 & 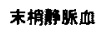 \\
\hline \multirow{2}{*}{$\begin{array}{l}\text { NE } \\
\text { t }\end{array}$} & $\begin{array}{c}\text { 厈正常样 } \\
n=28\end{array}$ & $270 \pm 24^{*}$ & $78 \pm 10^{* *}$ & $\begin{array}{r}* * * n=11 \\
263 \pm 37\end{array}$ \\
\hline & $\begin{array}{c}\text { 时的大政 } \\
n=8\end{array}$ & $518 \pm 69^{\circ}$ & $346 \pm 53$ & $\begin{array}{r}* * n=4 \\
460 \pm 69\end{array}$ \\
\hline E & $\begin{array}{c}\text { 伍正常辟 } \\
n=28\end{array}$ & $190 \pm 37$ & $31 \pm 5^{\prime}$ & $\begin{array}{r}n=11 \\
145 \pm 24 \\
\end{array}$ \\
\hline 值 & 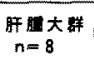 & $202 \pm 52$ & $150 \pm 48^{\dagger}$ & $\begin{array}{r}n=4 \\
145 \pm 49\end{array}$ \\
\hline
\end{tabular}

36例すべての例で肝静脈血NE值は動脈血NE值 より低く，又末梢静脈血も同時に採血した15例で は，全例で肝静脈血NE值は末梢静脈血NE値より 低値を示した。

肝正常群 の 血中NE值は, 動脈血 $270 \pm 24 \mathrm{ng} / l$, 肝静脈血 $78 \pm 10 \mathrm{ng} / l$, 末梢静脈血 (11例) $263 \pm 37$ $\mathrm{ng} / l$ であつた、肝隀大群では動脈血 $518 \pm 69 \mathrm{ng} / l$, 肝静脈血 $346 \pm 53 \mathrm{ng} / l$ ，末梢静脈血 ( 4 例) $460 \pm$ 69ng/lであつた。動脈血NE值，末梢静脈血NE值 は両者とも肝尰大群が肝正常群より有意に高く $(\mathrm{P}<0.001, \mathrm{P}<0.05)$, 肝静脈血も同様に肝尰 大群が肝正常群より有意に高値であつた $(\mathbf{P}<$ $0.001)$.

2. 血中epinephrine (E) 值（表 1, 図 2) $\mathrm{NE}$ と同様，全例において 肝静脈血 $\mathrm{E}$ 值は動脈 血および末梢静脈血の $\mathrm{E}$ 值より低い值を示した。

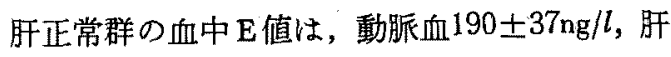
静脈血 $31 \pm 5 \mathrm{ng} / l$ ，末梢静脈血（11例） $145 \pm 24 \mathrm{ng} / l$ であつた．肝腫大群では動脈血202土52ng/l, 肝静 脈血 $150 \pm 48 \mathrm{ng} / l$ ，末梢静脈血 ( 4 例) $145 \pm 49 \mathrm{ng} / l$
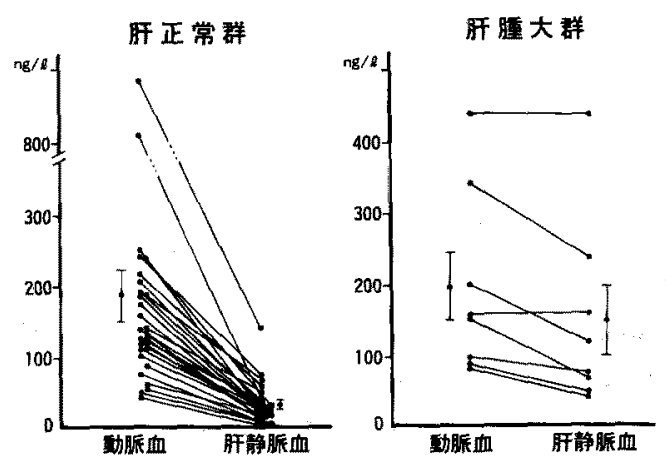

图 2、血中 $\mathrm{E}$ 值

であつた．動脈血 $\mathrm{E}$ 值，末梢静脈血 $\mathrm{E}$ 值は両群間 で注ぼ等しく，一方肝静脈血 $\mathbf{E}$ 值は肝腫大群が肝 正常群より有意に高值であつた $(P<0.001)$.

\section{3. 肝のCA代謝率 (図 3)}

先に示した式により肝でのNEおよび $\mathrm{E} の$ 代謝 率を求めた。肝のNE代謝率は肝正常群では71.3

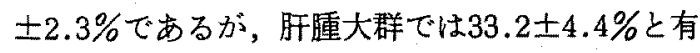
意に低值を示した $(\mathrm{P}<0.001)$. 同様に $\mathrm{E}$ 代謝率 ๖肝正常群 $80.8 \pm 2.1 \%$ に対して，肝腫大群では $30.9 \pm 7.8 \%$ と有意に低下していた $(P<0.001)$. 肝のCA代謝率をNEと Eとで比較すると，肝正常 群，肝腫大群のいずれの群に扣いてる有意差は認 められず，NEと $\mathrm{E} は$ 肝において同程度の代謝を 受けると考えられる。

肝のCA代謝率と肝静脈血CA值との関係をみる

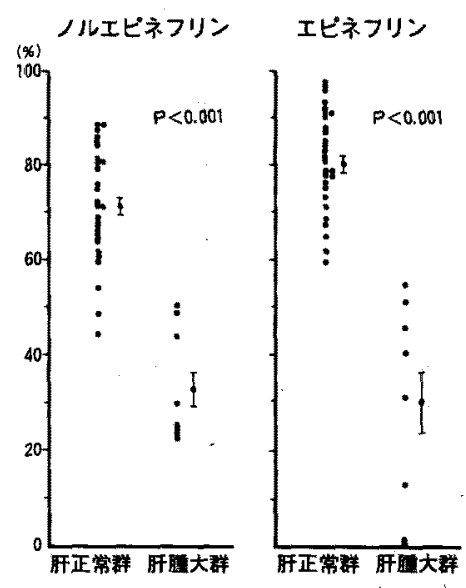

図 3.肝 のCA代謝率 


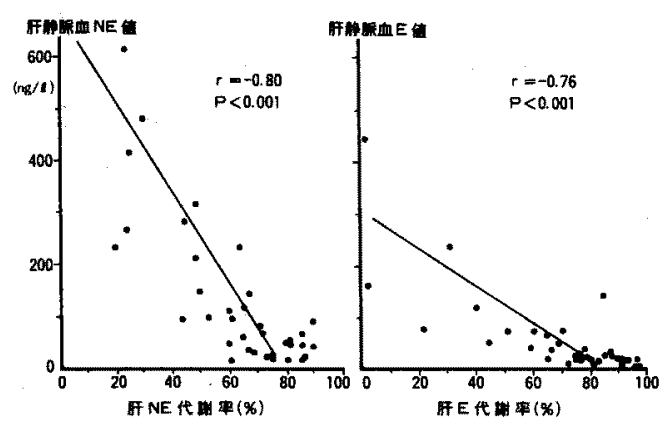

図 4.肝のCA代謝率と肝静脈血CA值

と(図 4), 肝のNE代謝率と肝静脈血NE值, 肝 の $\mathrm{E}$ 代謝率と肝静脈血 $\mathrm{E}$ 值との間には括の和の負 の相関がみられ（r=-0.80，P<0.001; $\mathrm{r}=-$ $0.76, \mathrm{P}<0.001)$, 肝のCA代謝率の低下に伴い肝 静脈血CA值が上昇していくことが示される.

4. 心血行力学测定值 (図 $5 ， 6$ )

各種の心血行力学測定值と肝のCA代謝率との 関連を検討した。

肝 のNE代謝率と肺動脈抎張末期圧 (PEDP) との間には有意の負の相関があり $(r=-0.62$, $P<0.01$ ), 又肝の NE代謝率之肺動脈楔入平均圧 (mPWP) との間にも負の相関がみられた（r=$0.63 ， \mathrm{P}<0.01)$. すなわち肝のNE代謝率は，心 不全の悪化にほぼ比例して低下していくことが考 えられる。

一方肝の $\mathrm{E}$ 代謝率とPEDP，mPWPとの間にも おのおの負の相関が双られ $(\mathrm{r}=-0.80, \mathrm{P}<0.01$; $\mathrm{r}=-0.72, \mathrm{P}<0.01), \mathrm{NE}$ と同様肝の $\mathrm{E}$ 代謝率子

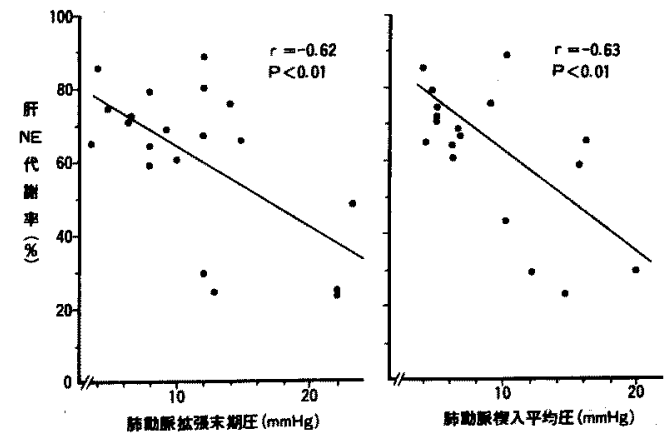

図 5、肝のNE代謝率とPEDP; mPWP との関係

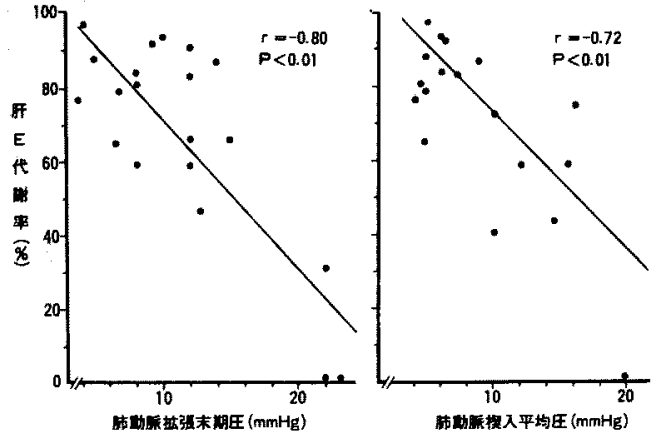

図 6、肝の $\mathrm{E}$ 代謝率とPEDP, mPWP との関係

心不全の悪化に比例して低下していくと考えられ る.

肝のNE，E代謝率之心拍出量，右房圧との間に はおのおの有意の相関はみられなかつた。

\section{5. 肝血流量}

12例の肝血流量は284 792 $\mathrm{ml} / \mathrm{min} / \mathrm{m}^{2}$ と種々の 值を示すが，肝正常群（9例）では569土43ml/ $\mathrm{min} / \mathrm{m}^{2}$, 肝腫大群 ( 3 例) では $410 \pm 66 \mathrm{ml} / \mathrm{min} / \mathrm{m}^{2}$ と肝腫大群で減少する傾向がみられた。

肝血流量と動脈血および肝静脈血CA值との間 に一定の関係はみられなかつた. 肝血流量と肝の CA代謝率との関連をみると，肝腫大群では肝正 常群に比し肝血流量, 肝のCA代謝率ともに低下 していたが，両釈数の間に有意の相関はみられな かつた.

\section{6. 肝のCA代謝量}

肝血流量を測定した12例において肝のCA代謝 量を，(動脈血 $\mathrm{CA}$ 值一肝静脈血 $\mathrm{CA}$ 值) $\times$ 肝血将流 量 $(\mathrm{ng} / \mathrm{min})$ として求めると, 肝のNE代謝量は $35 \sim 231 \mathrm{ng} / \mathrm{min}, \mathrm{E}$ 代謝量は14〜138ng $/ \mathrm{min}$ と種 ヶ の值を示した。両群間の比較では肝正常群（9

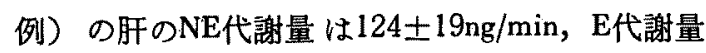

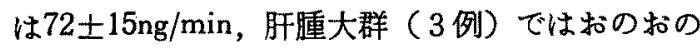
$86 \pm 27 \mathrm{ng} / \mathrm{min}, 50 \pm 17 \mathrm{ng} / \mathrm{min}$ と肝のCA代謝量は肝 腫大群に括いて低下寸る傾向にあつたが，有意の 差は認められなかつた。

\section{7. 肝機能検查值}

血液生化学検查の諸値, GOT, GPT, alk-P-ase, 
LDH, $\gamma \mathrm{GTP}, \mathrm{LDH}, \mathrm{TTT}, \mathrm{ZTT}$, 総ビリルビン, 血 清蛋白分画について検討し, 肝腫大群 8 例中 5 例 に種々の肝機能異常を認めた。これらを列記する 之症例 1. alk-P-ase $242 \mathrm{mU} / \mathrm{ml}$, GOT $50 \mathrm{mU} / \mathrm{ml}$, GPT $80 \mathrm{mU} / \mathrm{ml}$. 症例 2 . GOT $67 \mathrm{mU} / \mathrm{ml}$, GPT $82 \mathrm{mU} / \mathrm{ml}$, TTT $8.8 \mathrm{KU}$, 症例 3 . TTT $7.3 \mathrm{KU}$, 総蛋白 $5.4 \mathrm{~g} / \mathrm{dl}$, 総ビリルビン $1.9 \mathrm{mg} / \mathrm{dl}$, 症例 4 . $\gamma \mathrm{GTP} 151 \mathrm{mU} / \mathrm{ml}$. 泟例 5 . フルブミン $58.4 \%$ と 症例によつて様々に異なり，又その障害の程度は 比較的軽く, 肝腫大の大きさとの間に一定の傾向 をみなかつた，又これらの検查值と動脈血CA值， 肝静脈血CA值，肝のCA代謝率括よび肝血流量之 の間にはそれぞれ有意の相関はみられなかつた。

\section{8. 褐色細胞腫}

褐色細胞腫 2 例について同椂の検討を加えた。

2 例とも肝は正常と考えられた。

第 1 例は発作型褐色細胞腫であり，桧査施行時 の血纴は正常であつた．動脈血NE值755ng/ $l, E$ 値 $921 \mathrm{ng} / l$, 肝静脈血NE值 $190 \mathrm{ng} / l, E$ 值 $187 \mathrm{ng} / l$, 旰の $\mathrm{NE} ， \mathrm{E}$ 代謝率は括のおの $74.8 \% ， 79.7 \%$ あつ た.

第 2 例 は持続型褐色 細胞腫で, 動脈血NE値 $14904 \mathrm{ng} / l$, E值 $2316 \mathrm{ng} / l$, 肝静脈血NE值 $3805 \mathrm{ng} / l$,

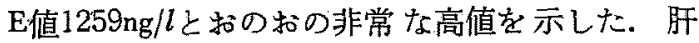
のNE代謝率は74.5\%，E代謝率は45.6\%であつ た. 肝血流量は $606 \mathrm{ml} / \mathrm{min} / \mathrm{m}^{2}$ であり，先に示した 式により求めた肝のNE代謝量は6526ng/min，E代

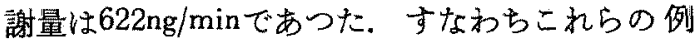
では血中CA値は非常な高値を示すが，同時に肝 のCA代謝率も高く多量のCAが肝で代謝されてい ると考えられる。

\section{考案}

肝が血中CAの不活化に一定の役割を演してい ることは従来より知られているが，その実際につ いては不明の点も多く, 特に病的状態でどう変化 するかについてはいなだ明確でない，今回の成績 からヒトの正常の肝では循環血中NEの約 $70 \%, \mathrm{E}$ の約80\%が取り込まれていることが示され，又と の取り込みはNEとEとの間で特に差がなく、ほぼ
同様の率で行なわれていると考えられた. Jones ${ }^{2)}$ らはイヌの動脈血と肝静脈血の $\mathrm{E}$ 值を測定し, 循 環血中 $\mathrm{E} の 45 \sim 70 \% か ゙$ 肝で取り込まれると述へたた が，これはEを持続注入している時の成績で，動 脈血と肝静脈血の $\mathrm{E}$ 值悱常に高い值を示してお り生理的状態とは異なつている. 今回の成績は七 トの生理的状態下のものであるが，これからはさ らに多量のCAが肝で取り込まれていると考えら れる。

肝は腹舫内最大の臓器 であり，心拍出量の約 1/4の血流量がある，従つて肝で血中CAの70 80 \%が取り込まれているとすると，全循環血中CA の約20\%が肝で代謝を受けると推定でき，一方今 回の成績から肝のNE，E代謝率の低下に伴い肝静 脈血のNE，E值が上昇していくことが認められ， これらの点から循環血中CAの動態に胝が種々の 影響を与えていることが示唆される。

肝でのCA取り込みの場について，肝の解剖を みると，輸入血管である肝動脈と門脈は肝内で細 かく枝分かれした後，合流して類洞に入り，ここ でDisse整を隔てて肝細胞に接している，物質代 謝やガス交換はこの類洞において行なわれ，血 中CAむ同様と考えられるがその実際は明確でな い. 又肝のCA取り込みの機序がuptake 2 のそれ と同一か否かも不明な点であるが，今回の成績か らは肝のCAの取り込み方にNEと $\mathrm{E}$ の間で差がな く, 一方uptake 2 ではNEとEとで取り込质が かなり異なつていると報告视されて和り，この 点からは肝でのCA取り込みの機序はuptake 2 と 異なり，肝の構造に由来する独自のるのである可 能性がある。

肝疾患儿招いて肝機能が高度に障害され肝不全 に進展すると, 肝性脳症等と共に循環動態の異常 が出現してくること!(1011)が従来より認められて いる，その成因としては種々の仮説があげられて いるが，最近ではCA代謝の異常によるとする報 告も多い，Goodall' ${ }^{12)}$ らはルコール性肝硬変患 者において，放射性同位元素を標識したNEと， ルメタネフリンを静注し，その底中代謝産物を調 
べ肝障害時のCA代謝を検討した。 その結果，本 症患者ではCOMTとMAOの活性が低下している ことが認められ，その原因として肝細胞とその酵 素の減少执よび肝循環の障害が関与していると考 えられた. 又Bloom ${ }^{13)} ら は$ は肝障害時の胆汁酸塩の 增加によつてưtake 2 による取り込み機序が阻害 される可能性を述べこれによつて 血中CA濃度 の相対的增加があり得るとしている.しかしこれ

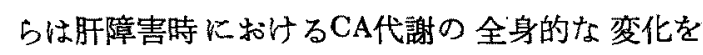
示したもので，肝自体におけるCA代謝の変動に ついての報告はみられない，今回は心不全からの らつ血肝を伴ら患者において肝のCA代謝を検討 し，5つ血肝でのNE代謝率は $33.2 \% ， \mathrm{E}$ 代謝率 は30.9\%と肝が正常の場合に比べ著明に低下して いることが認められた. この肝のCA代謝率の低 下，特にNEのそれに対しては肝でのNE遊出の増 加とNE取り込みの低下の両面を考慮する必要が ある. 本研究に执いてはこの両者を明瞭に区別す ることはできないが，肝でのCA遊出増加の機序 としては対象となつている心不全患者においてみ られる全身の交感神経活動の九進が関与している 可能性があり，又肝でのCA取り込み低下の機序と してはらつ血肝での病理的変化が関与すると思わ れ，類洞の払大と小葉中心性壊死によつて肝細胞 の破壇と線維化が進み, 又血流の停滞も加わつて その場での物質代謝の機能が低下し, さらに肝細 胞の破壊と数の娍少により肝に含まれるCOMT, $\mathrm{MAO}$ 量も低下していること等が考えられる.

本成績の動脈血CA值をみると，旰腫大群の動 脈血NE值は肝正常群のそれより有意に高值であ つた.このことはらつ血性肝腫大を伴う症例では 心不全の程度が明らかに強くこれまでの報告 で, 心不全患者の血中NE值は正常者に比べ高値で あり,さらに又NYHA機能分類でIII, IV群はI, II群より有意に高いといら ${ }^{14) 15}$ 成績と一致する。 この機序としては心不全時における全身の交感神 経活動の六進が大きく作用すると思われるが，血 中のCA濃度は体内に拈いて分泌されるCA量と不 活化されるCA量との総和であることから，一部
にはらつ血肝におけるCA代謝率の低下す関与し ていることが考えられる. 一方肝でのCA代謝量 をみると，肝腫大群ではNE，E代謝量とす肝正常 群に比し低下寸る傾向にはあつたが，有意の差は 認められなかつた。このことは肝血流量を測定し 得た例が少なかつた為もあるが，肝腫大群で肝の CA代謝率が低下している例でる，血中CA濃度の 高い時は肝でのCA代謝量が多くなつてくる場合 がある為と考えられる。

すなわち肝腫大群での肝のCA代謝量が正常よ り軽度減少あるいは不変であつたことから，5つ 血肝を伴5心不全患者において肝のCA代謝率の 低下が直接循環血中CA濃度の上犁をむたらすと はいい難いが，一方では全身からのCA放出の増 加があるためその濃度上昇の維持に関与している 可能性は考えられる.

心不全時の肝障害を血行動態の面からみた場 合，心疾患の違いによる特異的な差はなく，程度 の差はあつても肝障害の形は本質的に同一と考壳 られる。全は一般に多少とも左右両心不全の 要素を持つが, 従来肝障害に対しては右心不全の 要素がより重視されてきた。しかし小葉中心性壊 死の成因には，右心系の王上昇による機械的因子 と, 酸素供給の低下による化学的因子の両者が関 与しているとされ，実験的には肝血流量と肝静脈 圧を正常に保つた状態でも低酸素血症にすると同 じ病変を生じるとから ${ }^{16)}$, 酸素欠乏が小葉中心 性壊死により大きな役割を演じると考えられてい る. 臨床的にもCohenら ${ }^{17}$ は，諸検查にて左心不 全のみと診断される 4 症例に扎いて肝腫大を認 め, 組織学的には小葉中心性壊死の所見をみてそ れらの変化は左心不全の結果肝への循環障害が生 し，肝への酸素供給が不充分になる為であろらと 考察した。これらの観点からみた場合, 本成續に 颃いて肝のNE，E代謝率がPEDP，mPWPと逆相 関し、これらの圧が高くなる程低下していく所見 は興味深く, 本来これらの王は左心機能を表わす 指標とされるが，前に述べた理由から肝小葉中心 静脈周辺の肝細胞壊死の程度は左心不全の重症度 
にも比例すると考えられ，これらの圧が肝障害の 強さをある程度反映しているるのと思われる. 又 理学的乱よび血液生化学的に肝腫大, 肝機能障害 を認めない中等度心不全例でも，PEDP，mPWP の高い例では心不全による肝障害が多少とも生じ て打り，肝でのCA代謝率も低下している可能性 がある.

今回右房圧と肝のCA代謝率 との間に 有意の 相 関はみられなかつたが，これは症例により利尿薬 等の心不全の治療が行なわれて怙り，右房圧はこ れらの影響で容易に変動する為と思われる。

肝血流量は肝腫大群が肝正常群に比し有意で はないが隇少する傾向にあつたが，このことは Myers $^{18)} ら か ゙$ 述べた様に心不全患者では肝血流量 が正常人より低下しており，一方肝腫大群では心 不全の程度が肝正常群より明らが強いことと関 連すると思方れる。肝血流量は交感神経刺激ある いはNE，Eの投与により変化することが知られて いる、NE，Eの作用については投与部位，投与量 によつて異なり一定でないが，一般にNE，Eとる 肝血流量を減少させると考えられる，今回の成績 からは動脈血および肝静脈血CA値と肝血流量 と の間に一定の関係忹認められず，生体内での内因 性CAの肝血流量に及ぼす影響は小さいと考えら れる。肝血流量と肝のCA代謝率との間には今回 有意の相関はみられなかつたが，肝腫大群では肝 血流量の減少と肝のCA代謝率の低下が伴つてみ られることから，さらに症例を重ねれば一定の傾 向が見出せる可能性がある。

褐色細胞腫患者での肝のCA代謝を検討すると， 血中CA濃度は非常な高值を示すが肝のCA代謝率 はほぼ正常であり，持続型褐色細胞腫症例の肝の $\mathrm{NE}$ 代謝量は6500ng/minの多量に及んだ。このこ とから肝のCA代謝の容量は非常に大きいと推察 され，少なくとも内因性のCA濃度の変動範囲内 では肝のCA代謝量に制限はないと考えられる. 又肝が正常であれば動脈血CA值が高くても肝の CA代謝率は高值であり，肝のCA代謝率は輸入血 管のCA濃度の変動によらず肝の状態によつて左
右されると考えられる.

以上動脈血と肝静脈血のCA值から肝のCA代謝 について険討を加えたが，肝の輸入血管には肝動 脈と共に門脈があり，門脈は消化管でのCAの分 泌代謝を反映する。，七トの門脈血婇血は困難で今 回行なつていないか今後検討を要する問題と思わ れる. 又血中CAの不活化には種々の機序があり， そのいずれがより重要かは決定し難く条件によっ ても変化する. 今回肝障害時における肝のCA代 謝率の低下について述ベたが，この様な場合他の 取り込及機序がどら変化するかについても考慮す ベき問題と思われる.

結 論

種々の心疾患患者で 動脈血, 肝静脈血のCA值 を測定し，肝のCA代謝について検討した。

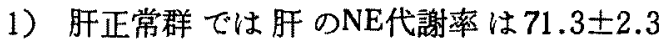
$\% ， \mathrm{E}$ 代謝率は80.8土2.1\%と多量のCAが肝で代 謝されていた。

2）5つ血性肝腫大群でこれらの值は，おのお

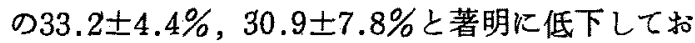
りこの代謝率の低下がらつ血性心不全患者での 血中CA濃度の值に一部関与している 可能性 があ る.

3）肝のNE，E代謝率はPEDP，mPWP とおの 打の逆相関し，心不全の重症度に注ほ比例して低 下していくと考えられる。

4）褐色細胞腫症例で代表される様に，正常の 肝でのCA代謝の容量は非常に大さいと考えられ る.

\section{文献}

1) Iversen LL: The uptake of catecholamines at high perfusion concentration in the rat isolated heart: A novel catecholamine uptake process. Brit J Pharmacol 25: 18, 1965.

2) Axerlrod J and Tomchick R: Enzymatic Omethylation of epinephrine and other catechols. J Biol Chem 233: 702, 1958.

3) Vendsalu A: Studies on the adrenaline and noradrenaline in human plasma. Acta Physiol Scand suppl 173: 1, 1960.

4) Elliot TR: The action of adrenaline. J Physiol 32: 401, 1905. 
5) Caesar J, et al: The use of indocyanine green in the measurement of hepatic blood flow as a test of hepatic function. Clin Sci $21: 43,1961$.

6) Miura $Y$, et al: Plasma catecholamines via an improved fluorimetric assay: Comparison with an enzymatic method. J Lab Clin Med 89: 421, 1977.

7) Jones RT and Blake WD: Dynamics of epinephrine distribution in the dog. Amer J Physiol 193: 365, 1958.

8) Callingham BA and Burgen AS: The uptake of isoprenaline and noradrenaline by the perfused rat heart. Mol Pharmacol 2: 37, 1966.

9) Kowalski HJ and Abelmann WH: Cardiac output at rest in Laennec's cirrhosis. J Invest 32: 1025, 1953.

10) Murray $J$, et al: Circulatory changes in chronic liver disease. Amer J Med 24: 358, 1958.

11) Fritts HW: Systemic circulatory adjustment in hepatic disease. Med Clin North Amer 47: 563, 1963.
12) Goodal $M$, et al: Noradrenaline and normetadrenaline metabolism in portal cirrhosis. Amer J Physiol 207: 1087, 1964.

13) Bloom DS, et al: Modification of the cerebrovascular response to noradrenaline by bile duct ligation. Gut 16: 732, 1975.

14) Thomas JA and Marks BH: Plasma norepinephrine in congestive heart failure. Amer J Cardiol 41: 233, 1978.

15）小林公也，他：心疾患における血中カテコール アミン濃度：心カテーテル測定値との相関。 第52回 日本内分泌学会総会抄録. 日内分泌誌 $55: 581,1979$.

16) Dunn GD, et al: The liver in congestive heart failure -a review-. Amer J Med Sci 265: 174, 1973.

17) Cohen JA and Kaplan MM: Left-sided heart failure preseting as hepatitis. Gastroenterology $74: 583,1978$.

18) Myers JD and Hickam JB: An estimation of the hepatic blood flow and splanchinic oxygen consumption in heart failure. $\mathrm{J}$ Clin Invest 27: 620, 1948. 